\title{
SERUM LEVEL OF THE HUMAN ANTIMICROBIAL CATHELICIDIN (HCAP18/LL-37) IN PATIENTS WITH PSORIASIS VULGARIS
}

\author{
Stoyan Pavlov ${ }^{1}$, Irina Ivanova ${ }^{2}$, Daniela Gerova $^{3}$, Trifon Chervenkov ${ }^{4}$, Svetlozar Balev $^{5}$ \\ ${ }^{1}$ Clinic of Dermatology and Venereology, Medical University of Varna \\ ${ }^{2}$ Clinic of Gastroenterology, Medical University of Varna \\ ${ }^{3}$ Clinical Laboratory, Medical University of Varna \\ ${ }^{4}$ Clinical Immunology, Medical University of Varna \\ ${ }^{5}$ Department of Clinical Medical Sciences, Medical University of Varna
}

\begin{abstract}
INTRODUCTION: Psoriasis is a chronic immune-mediated inflammatory disease. Human cathelicidin (hCAP18/LL37) has been elucidated recently as a modulator of inflammation in the affected skin. Vitamin D may induce expression of this antimicrobial peptide. Our trial aimed to study the circulating level of hCAP18/LL-37 and to explore its relationship with the severity of psoriasis.

MATERIALS AND METHODS: 79 patients with moderate to severe psoriasis (PASI $>10$ ) were included in a retrospective analysis. Stored serum samples were used for assessment of 25-hydroxyvitamin D - 25(OH)D and to measure the circulating human cathelicidin (LL-37).

RESULTS: In a study group of 79 patients we assessed mean level of 25(OH)D of $30.25 \mathrm{nmol} / 1$ (95\% CI 25.87 - $34.62 \mathrm{nmol} / \mathrm{l})$. Mean circulating cathelicidin was $27.17 \mathrm{ng} / \mathrm{ml}(95 \%$ CI $21.52-32.83 \mathrm{ng} / \mathrm{ml})$. Only $8.9 \%$ of patients had LL-37 level $>54 \mathrm{ng} / \mathrm{ml}$. Although circulating LL-37 was lower in severe psoriasis than in moderate psoriasis $(24.33 \mathrm{ng} / \mathrm{ml}$ vs. $31.14 \mathrm{ng} / \mathrm{ml})$, the variation was nonsignificant. We further evaluated the association of LL-37 with both PASI score and 25(OH)D concentration in the subgroup of patients with vitamin $D$ deficiency $(n=39)$. It was interesting to find a significant correlation between the level of LL-37 and 25(OH) $\mathrm{D}(\mathrm{r}=\mathbf{0 . 3 8}, \mathrm{p}=0.017)$ and an inverse association between the level of LL-37 and PASI $(\mathrm{r}=-\mathbf{0 . 3 0}, \mathrm{p}=0.06)$.

CONCLUSION: In this pilot trial we assessed low serum levels of cathelicidin antimicrobial peptide in patients with psoriasis. LL-37 may be discussed as related to PASI and 25(OH)D in a subgroup of psoriatic patients with vitamin D deficiency.
\end{abstract}

Keywords: Psoriasis, Vitamin D Deficiency, Cathelicidin Antimicrobial Peptide

Address for correspondence:

Stoyan Pavlov, MD

Clinic of Dermatology and Venereology

Medical University of Varna

55 Marin Drinov Str., Varna, Bulgaria

e-mail: stoyanpavlov@abv.bg

Received: April 7, 2016

Accepted: April 21, 2016

\section{INTRODUCTION}

Affected psoriatic skin has a characteristic excessive production of antimicrobial peptides (AMPs) like cathelicidin, beta-defensins and S-100 proteins. Typically, AMPs are small (12-15 amino acids) molecules, having positive charge and amphipathic structure that can be found in all live organisms, like insects, mammals and even plants (3). Humans contain only one cathelicidin family member called hCAP18/ 
LL-37. The name hCAP18 refers to an $18 \mathrm{kDa}$ peptide derived from the human Cationic Antimicrobial Protein. LL-37 is a 37-amino acids peptide, starting with a sequence of two 'Leucine-Leucine'. LL-37 was isolated for the first time from the polymorphonuclear leukocytes. It is accepted that hCAP18 indicates a pro-peptide, whereas LL-37 denotes a mature peptide, released from the C-terminus of hCAP18, having a potent and broad-spectrum of antimicrobial activity (4). LL-37, the human cathelicidin, represents "an elegant multifactorial effector molecule for innate immune defense of the skin" (5). Currently, LL-37 has been elucidated as a modulator of the development of psoriasis (3).

The concept of the important role of human cathelicidin was placed in 1997, by the report of Frohm et al. for the upregulation of LL-37 in psoriatic epidermis as well as other skin inflammatory disorders associated with disturbed barrier function of the epithelium. Authors hypothesized that LL-37 induction enhances the antimicrobial defense capacity of the skin (6). Recently, it was proven that LL-37 can also modify immune and growth response and this diverse biological activity depends on the pattern of oligopeptides, derived from LL-37 (7-12). Lande et al. found that LL-37 can form a complex with particles of self-DNA, capable to activate plasmacytoid dendritic cells (pDCs) so that they recognize self-DNA through Toll-like receptor 9 and in that way drive an inflammation response in psoriasis (13). Activated pDCs can initiate a large production of interferon-alfa (IFN- $\alpha$ ), leading to a step-way process of myeloid dendritic cell (mDC) activation, Th1/Th17 differentiation and consequent activation of the keratinocytes $(13,14)$.

The transcription of the cathelicidin gene is induced by the binding of a bioactive form of vitamin $\mathrm{D}, 1,25$-dihydroxyvitamin $\mathrm{D}$ to the vitamin $\mathrm{D}$ receptor. Dixon et al. suggested that the serum vitamin $\mathrm{D}$ may modulate the circulating level of LL-37 (15).

Our study aimed to evaluate the serum level of vitamin D and human cathelicidin (LL-37) in patients with psoriasis and investigate the relationship to the severity of the disease

\section{MATERIALS AND METHODS}

79 consecutively admitted patients in the Clinic of Dermatology and Venereology for initial evalu- ation and treatment of psoriasis were included in the retrospective study. At hospital admission our patients gave informed consent about necessary procedures. The patients with concomitant advanced kidney and liver disease, malabsorption, biologic systemic therapy and ultraviolet phototherapy, as well as vitamin D supplements intake were excluded from the study.

Psoriasis was diagnosed according to the clinical presentation and the consistent morphology findings in the skin biopsy. The type of psoriasis was categorized to: early type 1 (age below 40 at the initiation of the disease) and late type 2 (patient's age at diagnosis $\geq 40)(16) 147$ patients suffering from psoriasis, evaluation of the age of onset revealed two peaks, one occurring at the age of 16 years (female. The disease severity was assessed by the Psoriasis Area and Severity Index (PASI) and three grades were defined: mild psoriasis (PASI $\leq 10)$, moderate one (PASI $>10$, $\leq 30$ ), and severe one (PASI > 30 up to 72). Also, we collected from medical records and analyzed the data about: age and gender of the patients; body mass index (BMI) and waist circumference (WC); lab results of the level of C-reactive protein (CRP); white blood count (WBC); glucose; cholesterol; triglycerides; high density lipoprotein's cholesterol (HDLc); creatinine and uric acid. Overweight and obesity were defined based on the WHO definition of $\mathrm{BMI} \geq 25$ and $\mathrm{BMI} \geq 30$. We used the International Diabetes Federation features for central obesity: waist circumference $\geq 94 \mathrm{~cm}$ in Europid men and $\geq 80 \mathrm{~cm}$ for Europid women.

Serum samples of the patients, stored in $-20^{\circ} \mathrm{C}$, were used for an assessment of the level of the marker for vitamin D status - 25-hydroxyvitamin D, $25(\mathrm{OH}) \mathrm{D}$, a principal circulating metabolite of vitamin $\mathrm{D}$ and to measure the circulating human cathelicidin - LL-37. Serum levels of $25(\mathrm{OH}) \mathrm{D}$ were calculated by an immunofluorescent test (ADVIA Centaur Vitamin D Total, Siemens) with assay range of 3.7 to $150 \mathrm{ng} / \mathrm{ml}(9.3-375 \mathrm{nmol} / \mathrm{l})$. The vitamin D status was classified as deficiency $(25(\mathrm{OH}) \mathrm{D}$ concentration $<25 \mathrm{nmol} / \mathrm{l})$, insufficiency $(25-75 \mathrm{nmol} / \mathrm{l})$, sufficiency ( $>75$ to $250 \mathrm{nmol} / \mathrm{l})$, and toxicity ( $>250 \mathrm{nmol} / \mathrm{l})$ $(17,18)$.

The level of LL-37 was measured with a Human cathelicidin antimicrobial peptide ELISA Kit (CUS- 
Stoyan Pavlov, Irina Ivanova, Daniela Gerova et al.

ABIO, American Research Products Inc.) for the quantitative determination of endogenic human cathelicidin concentrations in serum, plasma, cell culture supernates, tissue homogenates, with a detection range of $0.45 \mathrm{ng} / \mathrm{ml}$ to $30 \mathrm{ng} / \mathrm{ml}$ and a minimum detectable dose of LL-37 less than $0.11 \mathrm{ng} / \mathrm{ml}$.

The continuous variables were expressed as a mean value and standard deviation (SD) or as a mean value and a $95 \%$ confidence interval (CI). The differences between the variables were analyzed with the Mann-Whitney test and the Kruskal-Wallis test (in analyses of more than 2 independent variables). The relations between LL-37 level and $25(\mathrm{OH}) \mathrm{D}$, as well as disease characteristics were assessed using the Spearman correlation coefficients. The software used for the analysis was GraphPad Prism, a demo 6.07 version.

\section{RESULTS}

Our study included 43 male and 36 female patients with a mean age of 57 years (from 19 to 77 years). Type 1, early psoriasis, was registered in 42 patients (53.16\%) and type 2, late onset psoriasis, in 37 patients (46.84\%). The severity of the disease was defined as moderate (PASI $>10, \leq 30$ ) in 33 patients $(41.78 \%)$ and severe (PASI $>30)$ in 46 patients (58.22\%). The baseline characteristics of the study group are shown in Table 1.

Table 1. Baseline characteristics of included patients with psoriasis $(n=79)$

\begin{tabular}{|c|c|}
\hline Male/Female & $43 / 36$ \\
\hline Age, years & $56.92 \pm 12.34$ \\
\hline BMI & $29.64 \pm 7.17$ \\
\hline Waist circumference, $\mathrm{cm}$ & $98.90 \pm 23.02$ \\
\hline CRP, mg/l & $15.45 \pm 27.91$ \\
\hline WBC count, $\times 10^{12} / 1$ & $7.56 \pm 2.23$ \\
\hline Serum glucose, mmol/l & $6.80 \pm 3.96$ \\
\hline Serum cholesterol, mmol/l & $5.02 \pm 1.03$ \\
\hline Serum HDL cholesterol, $\mathrm{mmol} / \mathrm{l}$ & $1.43 \pm 0.55$ \\
\hline Serum triglycerides, mmol/l & $1.57 \pm 0.98$ \\
\hline Serum uric acid, mmol/l & $323.34 \pm 109.49$ \\
\hline Serum creatinine, $\mathrm{mmol} / \mathrm{l}$ & $83.69 \pm 20.58$ \\
\hline Early/Late type of psoriasis & $42 / 37$ \\
\hline PASI & $32.85 \pm 12.18$ \\
\hline
\end{tabular}

The prevalence of overweight and obesity was $36.7 \%$ and $35 \%$, respectively. Central obesity was presented in $80.5 \%$ of female and in $37.2 \%$ of male patients. Analyzing comorbidities, we found a high frequency of $33 \%$ of raised fasting plasma glucose $(\geq 5.6$ $\mathrm{mmol} / \mathrm{l}$ ) and of $13.9 \%$ of diabetes type 2 . Total blood cholesterol $>5.2 \mathrm{mmol} / \mathrm{l}$ was observed in $44.3 \%$ of the study group, but most of them had a borderline elevation and only 7 patients $(8.8 \%)$ had cholesterol above $6.2 \mathrm{mmol} / \mathrm{l}$. Similarly, raised triglycerides, $\geq 1.7$ $\mathrm{mmol} / \mathrm{l}$ and $\geq 2.2 \mathrm{mmol} / \mathrm{l}$ were assessed in $29.1 \%$ and $15.2 \%$ of the patients, respectively. Reduced HDLc $(<1.29 \mathrm{mmol} / 1$ in females and $<1.03$ in males $)$ was found in 19 patients (24\%). Elevated creatinine level corresponding to grade I chronic kidney failure was established in $8.9 \%$. Only 4 patients (5\%) had hyperuricemia.

We assessed mean level of 25(OH)D of 30.25 $\mathrm{nmol} / \mathrm{l}(95 \%$ CI 25.87 - $34.62 \mathrm{nmol} / \mathrm{l})$ in a study group of 79 patients with moderate to severe psoriasis. A status of deficiency was registered in 39 patients (49.4\%); insufficiency - in 37 patients (46.8\%). Therefore, only 3 patients (3.8\%) were classified as having vitamin D sufficiency.

The mean observed circulating LL-37 in the serum of our patients with psoriasis was $27.17 \mathrm{ng} / \mathrm{ml}$ (SD $25.25 \mathrm{ng} / \mathrm{ml}$; 95\% CI 21.52 - $32.83 \mathrm{ng} / \mathrm{ml}$; range 1.11 to $131.4 \mathrm{ng} / \mathrm{ml})$. Very few $-8.9 \%$ of patients had LL-37 level $>54 \mathrm{ng} / \mathrm{ml}$ and only 3 patients appeared to have a maximum level of LL-37 $>100 \mathrm{ng} / \mathrm{ml}(116$, 128 and $131 \mathrm{ng} / \mathrm{ml}$, respectively). Figure 1 shows the age-related non-significant variation of LL-37.

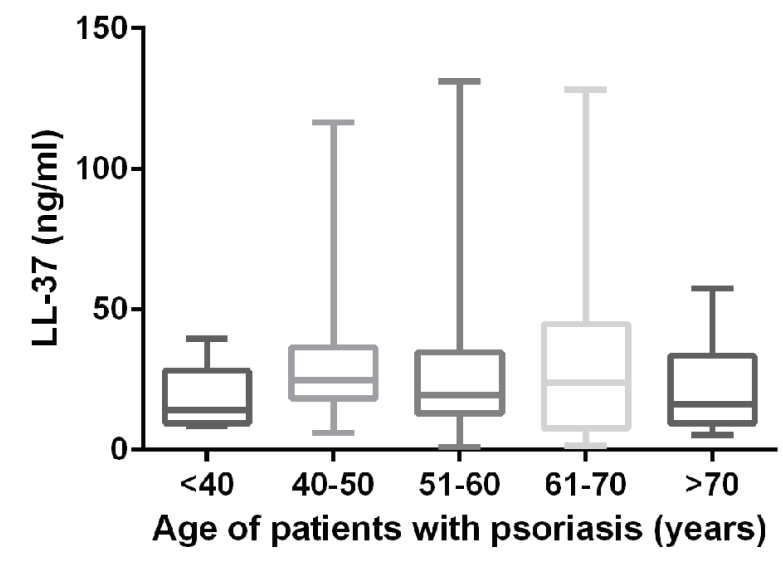

Figure 1. Level of circulating LL-37, according to the age of patients with psoriasis 
Table 2 shows the estimated levels of LL-37, according to the gender of the patients, the type and severity grade of psoriasis and the vitamin D status. $(\mathrm{r}=-0.16, \mathrm{p}=0.15)$. We failed to establish an association of the circulating LL-37 with $25(\mathrm{OH}) \mathrm{D}$ in the main group of 79 patients. There was a tendency for

Table 2. Level of LL-37 in the subgroups of 79 patients with psoriasis

\begin{tabular}{|c|c|c|}
\hline $\begin{array}{l}\text { Patient's characteristics / } \\
\text { subgroups }\end{array}$ & $\begin{array}{c}\text { LL-37 (ng/ml) } \\
\text { Mean level (95\% CI) }\end{array}$ & $P$ \\
\hline \multicolumn{3}{|l|}{ Gender: } \\
\hline * Male $(n=43)$ & $24.17(16.33-32.01)$ & 0.06, \\
\hline * Female $(\mathrm{n}=36)$ & $30.61(22.19-39.04)$ & $n s$ \\
\hline \multicolumn{3}{|l|}{ Type of psoriasis } \\
\hline * Type $1(n=42)$ & $26.77(20.64-32.90)$ & 0.25 , \\
\hline * Type $2(n=37)$ & $27.64(17.41-37.86)$ & $n s$ \\
\hline \multicolumn{3}{|l|}{ Severity grade of psoriasis } \\
\hline Moderate $(\mathrm{n}=33)$ & $31.14(20.97-41.30)$ & 0.29 \\
\hline Severe $(n=46)$ & $24.33(17.68-30.97)$ & $n s$ \\
\hline \multicolumn{3}{|l|}{ Vitamin D status } \\
\hline * Insufficiency $(\mathrm{n}=37)$ & $24.82(16.41-33.23)$ & 0.33 \\
\hline * Deficiency $(\mathrm{n}=39)$ & $26.49(19.79-33.19)$ & $n s$ \\
\hline
\end{tabular}

The subgroup analysis didn't find a significant difference in the patients' categories. Although circulating, LL-37 was lower in severe psoriasis (PASI $>30$ ) than in moderate psoriasis, mean level of 24.33 $\mathrm{ng} / \mathrm{ml}$ and $31.14 \mathrm{ng} / \mathrm{ml}$, the non-parametric t-test defined the variation as nonsignificant, Figure. 2.

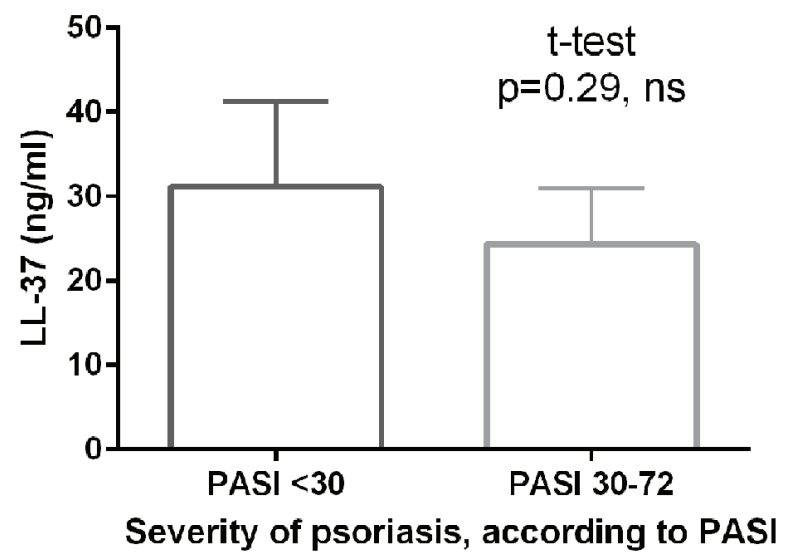

Figure 2. Level of circulating cathelicidin (LL-37) in the patients with moderate and severe grade of psoriasis

No significant association was observed between the estimated serum LL-37 and the analyzed patients' characteristics, such as: WC ( $\mathrm{r}=0.07)$; BMI $(\mathrm{r}=0.06)$; $\mathrm{CRP}(\mathrm{r}=0.10) ; 25(\mathrm{OH}) \mathrm{D}(\mathrm{r}=0.05)$ and PASI an inverse relationship between the LL-37 and PASI, but the level was not found to be significant.

We further evaluated the association of LL37 with both PASI and $25(\mathrm{OH}) \mathrm{D}$ concentration in the subgroup of patients with vitamin $\mathrm{D}$ deficiency $(n=39)$. It was interesting to find a significant correlation between the level of LL-37 and $25(\mathrm{OH}) \mathrm{D}(\mathrm{r}=0.38$, $\mathrm{p}=0.017)$ and an inverse association between the level of LL-37 and PASI ( $r=-0.30, p=0.06)$.

\section{DISCUSSION}

Psoriasis is a common immune-mediated skin disease. T-cells are involved in the pathogenesis, infiltrating the skin and secreting interferon-gamma and Th17 cytokines. An important fact is the chronic overexpression of human antimicrobial peptide hCAP18/LL-37 in psoriatic plaques, mainly released by infiltrating neutrophils and by keratinocytes $(6,13,14)$. LL-37 is able to trigger an activation of the innate immune cells (dendritic cells) and to break innate tolerance to self-nucleic acids. Lande et al., in a recent study, suggested the possible role of LL-37 also as a T-cell autoantigen in psoriasis. LL-37 is shown to be recognized by circulating T-cells in up to $75 \%$ of patients with moderate-to-severe psoriasis. LL-37-reactive T-cells produce Th17 cytokines and their detection correlates with the severity of psoriasis (PASI) 
Stoyan Pavlov, Irina Ivanova, Daniela Gerova et al.

(14). Considering the important role of LL-37 in the activation of both innate and T-cells immune cells in psoriasis, we designed that initial trial to test the circulating level of LL-37 in clinical settings.

Vitamin D deficiency and insufficiency in patients with psoriasis is a rising problem, documented by numerous studies $(15,19,20)$. In our reported group of 79 patients we observed a frequency of disturbed vitamin D status of $96.2 \%$.

Experimental studies on human tissues (cultivated epithelial cells, macrophages, neutrophils) demonstrated an increase of cathelicidin levels following administration of 1,25-dihydroxyvitamin D (21). Topical and oral vitamin D analogues can initiate a production of cathelicidines in the skin (22).

Few published clinical studies have investigated the relationship between the circulating $25(\mathrm{OH}) \mathrm{D}$ and the level of hCAP18/LL-37, showing contradictory results. The main opinion suggests a positive correlation between vitamin $\mathrm{D}$ and the level of cathelicidins (15,23-25). For example, a trial in patients with severe septic condition revealed vitamin $\mathrm{D}$ deficiency, low level of LL-37 (13.7 $\pm 2.1 \mathrm{ng} / \mathrm{mL})$, compared to circulating LL-37 in healthy controls $(27.2 \pm 4.9 \mathrm{ng} /$ $\mathrm{mL}$ ), mild positive correlation between LL-37 and $25(\mathrm{OH}) \mathrm{D}, \mathrm{R}=0.28$ (24). The other studies argue on the existence of a relationship between the $25(\mathrm{OH}) \mathrm{D}$ and LL-37, as a trial in patients with pulmonary tuberculosis (26) and a study of dialysis patients (27). A possible explanation will be that LL-37 correlates with the bioavailable $25(\mathrm{OH}) \mathrm{D}$, but not with the total 25(OH)D (28)placebo-controlled, trial. SETTING: Medical and surgical ICUs of a single teaching hospital in Boston, MA. PATIENTS: Thirty adult ICU patients. INTERVENTIONS: Placebo $(n=10$. Low LL37 was found in chronic dialysis patients(27), in neutropenia of various aetiologies (29), chronic obstructive pulmonary disease (30)deterioration in health status and risk of death. The assessment of exacerbation risk is important in the grading of COPD. The most common cause of COPD exacerbation is respiratory tract infection. The only known human cathelicidin antimicrobial peptide, LL-37, play an important role in innate defense against infection. Its gene expression is regulated by the bioactive form of vitamin D. The objective of the present study was to explore the relationship between LL-37 plasma levels, vitamin $\mathrm{D}$ status and exacerbation risk in patients with COPD.In\nMETHODS: COPD patients and normal subjects were recruited from Beijing Hospital for this study. COPD patients were divided into low risk group and high risk group according to the criteria of GOLD strategy. The plasma concentrations of LL-37 were measured by ELISA technique to explore the difference in LL-37 levels between groups. The plasma levels of 25-hydroxy vitamin D [25(OH, in human immunodeficiency virus-1 infected individuals not receiving antiretroviral therapy (31) and in patients with ST - Segment Elevation Myocardial Infarction (32). Much higher level of serum LL-37 was assessed in patients with chronic hepatitis B $(174.66 \pm 100.7) \mathrm{ng} / \mathrm{ml})$ and chronic hepatitis C (155.15 $\pm 78.84 \mathrm{ng} / \mathrm{ml})$; LL-37 concentration was not correlated with the documented vitamin $\mathrm{D}$ deficiency in the studied population with viral hepatitis (33).

The assessed blood LL-37 in psoriasis varies substantially. The median level of LL-37 was 11.78 $\mathrm{ng} / \mathrm{ml}$ (IQR $9.75-16.90 \mathrm{ng} / \mathrm{ml}$ ) in 76 studied patients with plaque and guttate psoriasis (34). Another trial assessed similar mean level of $18.16 \mathrm{ng} / \mathrm{ml}$ (range 9.1 to $35.9 \mathrm{ng} / \mathrm{ml}$ ) in 100 patients with psoriasis and co-morbidities; serum LL-37 was inversely correlated with 25(OH)D (35)a lot of co-morbidities (diabetes, obesity, heart disease, etc.. Much higher concentrations of $970 \mathrm{ng} / \mathrm{ml}$ were investigated in 61 psoriatic patients by Kanda et al. and the serum LL-37 did not correlate with the PASI score (36). The ultraviolet $B$ phototherapy lead to an increase of the circulating LL-37 (35)a lot of co-morbidities (diabetes, obesity, heart disease, etc..

In our study we observed a mean level of LL-37 of $27.17 \mathrm{ng} / \mathrm{ml}$ with a minimum level of $1.11 \mathrm{ng} / \mathrm{ml}$ and maximum level of $131.40 \mathrm{ng} / \mathrm{ml}$, but only $8.9 \%$ of our patients had a level of LL-37 > $54 \mathrm{ng} / \mathrm{ml}$. Therefore, we concluded of low circulating cathelicidin in our group patients with moderate to severe psoriasis.

Systemic LL-37 levels are highly variable among subjects included as control groups of the different published studies (15,23-36)1,25-dihydroxyvitamin $D$, to the vitamin D receptor. Significant levels of the protein hCAP18/LL-37 are found in the blood and may protect against infection and/or sepsis. We hypothesized that serum vitamin D levels may modulate the circulating levels of hCAP18. Only three 
studies have shown a positive correlation between circulating 25-hydroxyvitamin D and hCAP18 levels. Here we provide additional evidence for such a correlation in healthy, middle-aged adults. $\mid \mathrm{n} \backslash$ nFINDINGS: Serum levels of 25-hydroxyvitamin D [25(OH. Blood LL-37 is produced by a variety of cell types such as neutrophils, macrophages and epithelial cells. Other factors that may affect the circulating LL-37 are a lack of standard method for ELISA testing, variation by age, ethnicity, exposure to ultraviolet light and pathogens inducing LL-37, such as viral or bacterial infections. Previous studies commented that low circulating LL-37 in severe infections may be due to a rapid binding of LL-37 peptide to serum lipoproteins, as an effective LL-37 scavenging mechanism (37)we postulated that this inhibition results from binding of LL-37 to unidentified proteins. An LL-37 binding plasma protein has now been isolated by affinity chromatography. SDS-polyacrylamide gel electrophoresis of proteins that bound to an LL37 column revealed one band with a molecular mass of about $26 \mathrm{kDa}$, and amino acid sequence analysis identified the protein as apolipoprotein A-I (apoA-I. In our analysis we failed to establish an association of LL-37 level with markers of existing infection, as CRP and WBC count.

Bhan et al. hypothesized that a positive correlation between LL-37 and 25(OH)D exists only in individuals with a vitamin $\mathrm{D}$ deficiency, stating a threshold of $32 \mathrm{ng} / \mathrm{ml}(80 \mathrm{nmol} / \mathrm{l})$ below that a positive significant relationship of cathelicidin and $25(\mathrm{OH}) \mathrm{D}$ can be observed (38). Authors suggest that the biological effect of vitamin D on blood levels of hCAP18/LL-37 may be initiated only in the presence of 25(OH)D sufficiency (15).

In a subgroup analysis of 39 psoriatic patients with $25(\mathrm{OH}) \mathrm{D}<25 \mathrm{nmol} / \mathrm{l}$ we found a significant correlation between the level of LL-37 and 25(OH)D $(\mathrm{r}=0.38, \mathrm{p}=0.017)$ and an inverse association between the level of LL-37 and PASI ( $\mathrm{r}=-0.30, \mathrm{p}=0.06)$. Our study supports the concept of an association of LL37 and the severity of an immune-mediated disease, such as psoriasis. The relationship of LL-37 and PASI was demonstrated only in the patients with vitamin D deficiency.

\section{CONCLUSION}

Our study could contribute to the hypothesis considering the role of human cathelicidin, innate immune peptide in the pathogenesis of psoriasis. Further studies are required to focus on tissue expression of LL-37. In regard to the immune-modulating potential of cathelicidin there is a need to assess its role in the biological therapy of psoriatic patients.

\section{REFERENCES}

1. Enamandram M, Kimball AB. Psoriasis epidemiology: the interplay of genes and the environment. J Invest Dermatol. 2013; 133(2): 287-9.

2. Batycka-Baran, Maj J, Wolf R, Szepietowski JC. The new insight into the role of antimicrobial proteinsalarmins in the immunopathogenesis of psoriasis. J Immunol Res. 2014; Article ID 628289.

3. Morizane S, Gallo RL. Antimicrobial peptides in the pathogenesis of psoriasis. J Dermatol 2012; 39(3): 225-30.

4. Méndez-Samperio $P$. The human cathelicidin hCAP18/LL-37: a multifunctional peptide involved in mycobacterial infections. Peptides. 2010; 31(9): 1791-8.

5. Zaiou M, Nizet V, Gallo RL. Antimicrobial and protease inhibitory functions of the human cathelicidin (hCAP18/LL-37) prosequence. J Invest Dermatol. 2003; 120(5): 810-6.

6. Frohm M, Agerberth B, Ahangari G, Stahle-Backdahl M, Liden S, Wigzell H, et al. The Expression of the Gene Coding for the Antibacterial Peptide LL37 Is Induced in Human Keratinocytes during Inflammatory Disorders. J Biol Chem. 1997; 272(24): 15258-63.

7. De Yang, Chen Q, Schmidt AP, Anderson GM, Wang JM, Wooters J, et al. LL-37, the neutrophil granule- and epithelial cell-derived cathelicidin, utilizes formyl peptide receptor-like 1 (FPRL1) as a receptor to chemoattract human peripheral blood neutrophils, monocytes, and T cells. J Exp Med. 2000; 192(7): 1069-74.

8. Koczulla R, von Degenfeld G, Kupatt C, Krötz F, Zahler S, Gloe T, et al. An angiogenic role for the human peptide antibiotic LL-37/hCAP-18. J Clin Invest. 2003;111(11):1665-72.

9. Braff MH, Hawkins MA, Nardo AD, Lopez-Garcia B, Howell MD, Wong C, et al. Structure-Function Relationships among Human Cathelicidin Peptides: Dissociation of Antimicrobial Properties 
Stoyan Pavlov, Irina Ivanova, Daniela Gerova et al.

from Host Immunostimulatory Activities. J Immunol. 2005; 174(7): 4271-8.

10. Morioka Y, Yamasaki K, Leung D, Gallo RL. Cathelicidin antimicrobial peptides inhibit hyaluronan-induced cytokine release and modulate chronic allergic dermatitis. J Immunol. 2008; 181(6): 3915-22.

11. Mookherjee N, Brown KL, Bowdish DME, Doria S, Falsafi R, Hokamp K, et al. Modulation of the TLRMediated Inflammatory Response by the Endogenous Human Host Defense Peptide LL-37. J Immunol. 2006; 176(4): 2455-64.

12. Mookherjee N, Wilson HL, Doria S, Popowych $Y$, Falsafi R, Yu JJ, et al. Bovine and human cathelicidin cationic host defense peptides similarly suppress transcriptional responses to bacterial lipopolysaccharide. J Leukoc Biol. 2006; 80(6): 1563-74.

13. Lande R, Gregorio J, Facchinetti V, Chatterjee B, Wang Y-H, Homey B, et al. Plasmacytoid dendritic cells sense self-DNA coupled with antimicrobial peptide. Nature. 2007; 449 (7162): 564-9.

14. Lande R, Botti E, Jandus C, Dojcinovic D, Fanelli G, Conrad C, et al. The antimicrobial peptide LL37 is a T-cell autoantigen in psoriasis. Nat Commun. 2014; 5: 5621.

15. Dixon BM, Barker T, McKinnon T, Cuomo J, Frei B, Borregaard N, et al. Positive correlation between circulating cathelicidin antimicrobial peptide (hCAP18/LL-37) and 25-hydroxyvitamin D levels in healthy adults. BMC Res Notes. 2012; 5: 575.

16. Henseler T, Christophers E. Psoriasis of early and late onset: characterization of two types of psoriasis vulgaris. J Am Acad Dermatol [Internet]. 1985; 13(3): 450-6.

17. Krasowski MD. Pathology consultation on vitamin D testing. Am J Clin Pathol. 2011; 136(4): 507-14.

18. Nair R, Maseeh A. Vitamin D: The "sunshine" vitamin. J Pharmacol Pharmacother. 2012; 3(2): $118-26$.

19. Gisondi P, Rossini M, Di Cesare a, Idolazzi L, Farina S, Beltrami G, et al. Vitamin D status in patients with chronic plaque psoriasis. Br J Dermatol. 2012;1 66(3): 505-10.

20. Ricceri F, Pescitelli L, Tripo L, Prignano F. Deficiency of serum concentration of 25-hydroxyvitamin D correlates with severity of disease in chronic plaque psoriasis. J Am Acad Dermatol. 2013; 68(3): 511-2.
21. Liu PT, Stenger S, Li H, Wenzel L, Tan BH, Krutzik SR, et al. Toll-like receptor triggering of a vitamin D-mediated human antimicrobial response. Science. 2006; 311(5768): 1770-3.

22. Hata TR, Kotol P, Jackson M, Nguyen M, Paik A, Udall D, et al. Administration of oral vitamin D induces cathelicidin production in atopic individuals. J Allergy Clin Immunol. 2008; 122(4): 829-31.

23. Gombart AF, Borregaard N, Koeffler HP. Human cathelicidin antimicrobial peptide (CAMP) gene is a direct target of the vitamin $\mathrm{D}$ receptor and is strongly up-regulated in myeloid cells by 1,25-dihydroxyvitamin D3. FASEB. 2005; 19(9): 1067-77.

24. Jeng L, Yamshchikov A V, Judd SE, Blumberg HM, Martin GS, Ziegler TR, et al. Alterations in vitamin $\mathrm{D}$ status and anti-microbial peptide levels in patients in the intensive care unit with sepsis. J Transl Med. 2009]; 7:28.

25. Alvarez-Rodriguez L, Lopez-Hoyos M, Garcia-Unzueta M, Amado JA, Cacho PM, Martinez-Taboada VM. Age and low levels of circulating vitamin D are associated with impaired innate immune function. J Leukoc Biol. 2012; 91(5): 829-38.

26. Yamshchikov A V, Kurbatova E V, Kumari M, Blumberg HM, Ziegler TR, Ray SM, et al. Vitamin D status and antimicrobial peptide cathelicidin (LL-37) concentrations in patients with active pulmonary tuberculosis. Am J Clin Nutr. 2010; 92(3): 603-11.

27. Gombart AF, Bhan I, Borregaard N, Tamez H, Camargo CA, Koeffler HP, et al. Low plasma level of cathelicidin antimicrobial peptide (hCAP18) predicts increased infectious disease mortality in patients undergoing hemodialysis. Clin Infect Dis. 2009; 48(4): 418-24.

28. Quraishi SA, De Pascale G, Needleman JS, Nakazawa H, Kaneki M, Bajwa EK, et al. Effect of Cholecalciferol Supplementation on Vitamin D Status and Cathelicidin Levels in Sepsis: A Randomized, Placebo-Controlled Trial. Crit Care Med. 2015; 43(9): 1928-37.

29. Ye Y, Carlsson G, Karlsson-Sjöberg JMT, Borregaard N, Modéer TU, Andersson ML, et al. The antimicrobial propeptide hCAP-18 plasma levels in neutropenia of various aetiologies: a prospective study. Sci Rep. 2015; 5: 11685.

30. Yang Y-M, Guo Y-F, Zhang H-S, Sun T-Y. Antimicrobial peptide LL-37 circulating levels in chronic obstructive pulmonary disease patients with high 
risk of frequent exacerbations. J Thorac Dis. 2015; 7(4): 740-5.

31. Honda JR, Connick E, MaWhinney S, Chan ED, Flores SC. Plasma LL-37 correlates with vitamin $\mathrm{D}$ and is reduced in human immunodeficiency virus-1 infected individuals not receiving antiretroviral therapy. J Med Microbiol. 2014; 63: 997-1003.

32. Zhao H, Yan H, Yamashita S, Li W, Liu C, Chen Y, et al. Acute ST-Segment Elevation Myocardial Infarction is Associated with Decreased Human Antimicrobial Peptide LL-37 and Increased Human Neutrophil Peptide-1 to 3 in Plasma. J Atheroscler Thromb. 2012; 19(4): 357-68.

33. Iacob SA, Panaitescu E, Iacob DG, Cojocaru M. The human cathelicidin LL37 peptide has high plasma levels in B and C hepatitis related to viral activity but not to 25 -hydroxyvitamin D plasma level. Rom J Intern Med; 2012: 50(3): 217-23.

34. Hwang YJ, Jung HJ, Kim MJ, Roh NK, Jung JW, Lee YW, et al. Serum levels of LL-37 and inflammatory cytokines in plaque and guttate psoriasis. Mediators Inflamm. 2014; Article ID 268257.

35. Al-Mutairi N, El Eassa B, Nair V. Measurement of vitamin D and cathelicidin (LL-37) levels in patients of psoriasis with co-morbidities. Indian J Dermatol Venereol Leprol. 2013; 79(4): 492-6.

36. Kanda N, Ishikawa T, Kamata M, Tada Y, Watanabe S. Increased serum leucine, leucine-37 levels in psoriasis: positive and negative feedback loops of leucine, leucine-37 and pro- or anti-inflammatory cytokines. Hum Immunol. 2010; 71(12): 1161-71.

37. Wang Y. Apolipoprotein A-I Binds and Inhibits the Human Antibacterial/Cytotoxic Peptide LL-37. J Biol Chem. 1998; 273(50): 33115-8.

38. Bhan I, Camargo CA, Wenger J, Ricciardi C, Ye J, Borregaard N, et al. Circulating levels of 25-hydroxyvitamin $\mathrm{D}$ and human cathelicidin in healthy adults. J Allergy Clin Immunol. 2011; 127(5): $1302-4$. 